\title{
Histopathology and bioaccumulation in oysters Crassostrea virginica living on wood preserved with chromated copper arsenate*
}

\author{
Peddrick Weis ${ }^{1}$, Judith S. Weis ${ }^{2}$, John Couch $^{3}$ \\ ${ }^{1}$ Department of Anatomy, University of Medicine and Dentistry of New Jersey, Newark, New Jersey 07103, USA \\ ${ }^{2}$ Department of Biological Sciences, Rutgers University, Newark, New Jersey 07102, USA \\ ${ }^{3}$ U.S. Environmental Protection Agency, Gulf Breeze, Florida 32561, USA
}

\begin{abstract}
Oysters Crassostrea virginica living inside a residential canal lined with chromated copper arsenate (CCA) treated wood had elevated levels of metals, especially copper, and were sometimes green in color. Compared to reference oysters collected from nearby rocks, these oysters had an elevated prevalence of a previously described histopathological atrophic condition (metaplasia) of the digestive diverticula. The condition did not manifest itself, however, in reference site oysters that were transplanted into the canal for a 3 mo period, during which time they attained an average of twothirds of the resident canal oysters' copper level.
\end{abstract}

KEY WORDS: Chromated copper arsenate Crassostrea virginica - Oyster $\cdot$ Wood preservative

\section{INTRODUCTION}

The most common wood preservative currently in use is chromated copper arsenate (CCA), which has replaced creosote and pentachlorophenol, and is extensively used in the USA and elsewhere. The 3 elements, generally in the form of oxides, are pressurized into the wood in a process called 'Wolmanizing'. Wood intended for marine use receives $1.5 \mathrm{lbs} \mathrm{ft}^{-3}$ (ca $24.3 \mathrm{~kg}$ $\mathrm{m}^{-3}$ ) and, in Florida (USA), $2.5 \mathrm{lbs} \mathrm{ft}^{-3}$ (ca $40.5 \mathrm{~kg} \mathrm{~m}^{-3}$ ). Warner \& Solomon (1990) demonstrated that all 3 metals leach from treated wood placed in freshwater, and that leaching is greatest at lower pHs. Metals leach from the wood in seawater with the rates generally decreasing over time (Weis et al. 1991, 1992). Copper leached to the greatest extent (Warner \& Solomon 1990, Weis et al. 1991).

Chemicals leached from treated wood could be taken up by biota, particularly by epibiotic ('fouling') organisms that live directly on the wood. The 3 metals were found to be taken up by 2 species of green algae

- Contribution \#796 from the U.S. EPA Gulf Breeze Laboratory
(Ulva lactuca and Enteromorpha intestinalis), and by American oysters (Crassostrea virginica) living on CCA-treated wood (Weis \& Weis 1992). While Cu concentrations were elevated in oysters living on a CCA dock in open water, they were much higher in oysters growing inside a poorly flushed residential canal that was lined with CCA-treated wood bulkheads. Some of these oysters were green in color. Oysters can concentrate up to $600 \mathrm{ppm}$ wet weight of $\mathrm{Cu}$ (Schuster \& Pringle 1969). Published reports of green oysters (Ostrea edulis) date from the nineteenth century and identified $\mathrm{Cu}$ accumulation as the probable cause (Lankester 1886). Another observation of probable CCA-related green coloration and elevated $\mathrm{Cu}$ in American oysters was made by Couch \& Moore (unpubl. report to Florida Dept of Environmental Regulation, 1986) in which oysters living in an area in which poles of CCA-treated wood had been placed in the water were studied.

The accumulation of high concentrations of copper may not necessarily cause toxic effects to the oysters. Divalent cations are accumulated in granular hemocytes and transferred via metal-binding proteins (e.g. metallothioneins) to tertiary lysosomes, resulting in the 
sequestering of these metals by the cells (George et al. 1978, Thompson et al. 1985). These granular hemocytes then migrate by diapedesis across the mantle surface. There are no known comparable sequestration mechanisms for $\mathrm{Cr}$ or As. Schuster \& Pringle (1969) found accumulation of $\mathrm{Cr}$ in exposed oysters was 2 orders of magnitude below that of $\mathrm{Cu}$.

The current study was designed to investigate the histopathology and metal concentrations of oysters growing on CCA-treated wood as compared to those from a nearby reference site.

\section{MATERIALS AND METHODS}

Crassostrea virginica $(\mathrm{n}=20$ ) were collected in January from CCA-treated wood inside a residential canal in Santa Rosa Sound, Pensacola Beach, Florida. Reference organisms ( $\mathrm{n}=16$ ) were collected from rocks on the periphery of Sabine Island, $1200 \mathrm{~m}$ away from the entrance to the canal. Second collections from the canal $(n=11)$, the reference site $(n=12)$, and small ( $<1$ yr old) specimens growing on a new piling $(<1 \mathrm{yr}$ old) in the canal were taken in early May. Sufficent numbers of oysters from the reference site were caged inside the canal to permit monthly collected and collections ( $\mathrm{n}=12$ per month) for chemical analysis, and 12 were examined histologically in May (i.e. after 3 mo in the canal).

Histological condition was investigated by taking a cross-section from the middle of each oyster, preserving it in Bouin's fluid, embedding it in paraffin, and studying slides stained with hematoxylin and eosin. Special attention was given to the digestive gland diverticula. The condition of the epithelia of the digestive diverticula of each oyster was classified as 'A', 'B', ' $\mathrm{C}$ ', or ' $\mathrm{D}$ ' according to the mean percent of diverticulae in the conditions described and illustrated by Couch $(1984,1985)$. These letters reflect progressive metaplasia of the diverticula, with ' $A$ ' being normal and following letters reflecting decreasing cell height and increasing lumen size. Data were analyzed using a Wilcoxon rank test for 4 ordered responses, using exact p-values computed for small sample size by StatXact ${ }^{\circ}$ statistical software (Mehta \& Patel 1991).

For metal analysis, other oysters from the reference site, canal, and a CCA dock in an open water environment were wet-ashed in concentrated nitric acid (Baker, 'for trace metal analysis') at a maximum ratio of $0.2 \mathrm{~g}$ tissue wet weight $\mathrm{ml}^{-1}$ acid at $90^{\circ} \mathrm{C}$, and metals were measured by inductively-coupled argon plasma emission spectroscopy (ICAP) in a Jarrell-Ash series 800 instrument. This instrument was programmed to measure each sample 4 times; thus, each datum is the mean of these multiple measurements of each sample.
While organoarsenicals may not be ashed by $\mathrm{HNO}_{3}$, they are solubilized; anything which is in suspension or in solution will be volatilized and atomized when aspirated into the argon plasma $\left(10000^{\circ} \mathrm{C}\right)$. Quality assurance was performed using standard reference material N.I.S.T. SRM 1566 (oyster powder). Minimum detection levels, calculated as 3 standard deviations of the blanks, were typically $0.10,0.25$, and $0.50 \mathrm{ppm}$ for $\mathrm{Cu}, \mathrm{Cr}$, and $\mathrm{As}$ in wet tissues, and 1.00, 2.50, and 5.00 for dry tissue (SRM 1566). Copper measurements were $93.7 \% \pm 1.14$, Cr was below our minimum detection level in most cases, and As was more than 3 times the expected value of the SRM 1566. Standard additions of up to 10 ppm to preparations of SRM 1566 gave $104 \%$ and $100 \%$ of expected values for $\mathrm{Cu}$ and $\mathrm{Cr}$, respectively. For As, after baseline adjustment for nonspecific absorption (Fe and $\mathrm{Al}$ interfere with As analysis in ICAP), standard additions to SRM 1566 gave $107 \%$ of expected values; the regression line thus derived was used for As determination in the samples. Data were analyzed by analysis of variance, linear regression and t-tests with Bonferroni's adjustment.

\section{RESULTS}

Oysters from the 2 populations collected in January showed a significant difference in condition of their digestive diverticula (Table 1, Fig. 1). Canal oysters showed a higher prevalence of more severe lesions. Both groups of May oysters had generally a poorer condition of the diverticula, but the canal oysters still showed more severe metaplasia. However, the oysters that had been transplanted into the canal for 3 mo were not histologically different from the oysters remaining at the reference site.

No pathological lesions were apparent in any other organs or tissues.

Table 1 Crassostrea virginica. Number of oysters from different collections showing different conditions ( $A$ to $D$; see text) of digestive diverticula

\begin{tabular}{|lcccc|}
\hline Oysters & \multicolumn{4}{c|}{ Condition of diverticula } \\
& A & B & C & D \\
\hline Reference, Jan & 9 & 7 & 0 & 0 \\
Canal, Jan $^{a}$ & 6 & 5 & 9 & 0 \\
Reference, May $_{\text {Canal, May }}$ & 6 & 1 & 5 & 0 \\
Transplants & 1 & 3 & 4 & 3 \\
& 7 & 0 & 5 & 0 \\
$\mathrm{p}=0.012$ by Wilcoxon rank test & & \\
$\mathrm{p}=0.050$ by Wilcoxon rank test & & \\
\hline
\end{tabular}



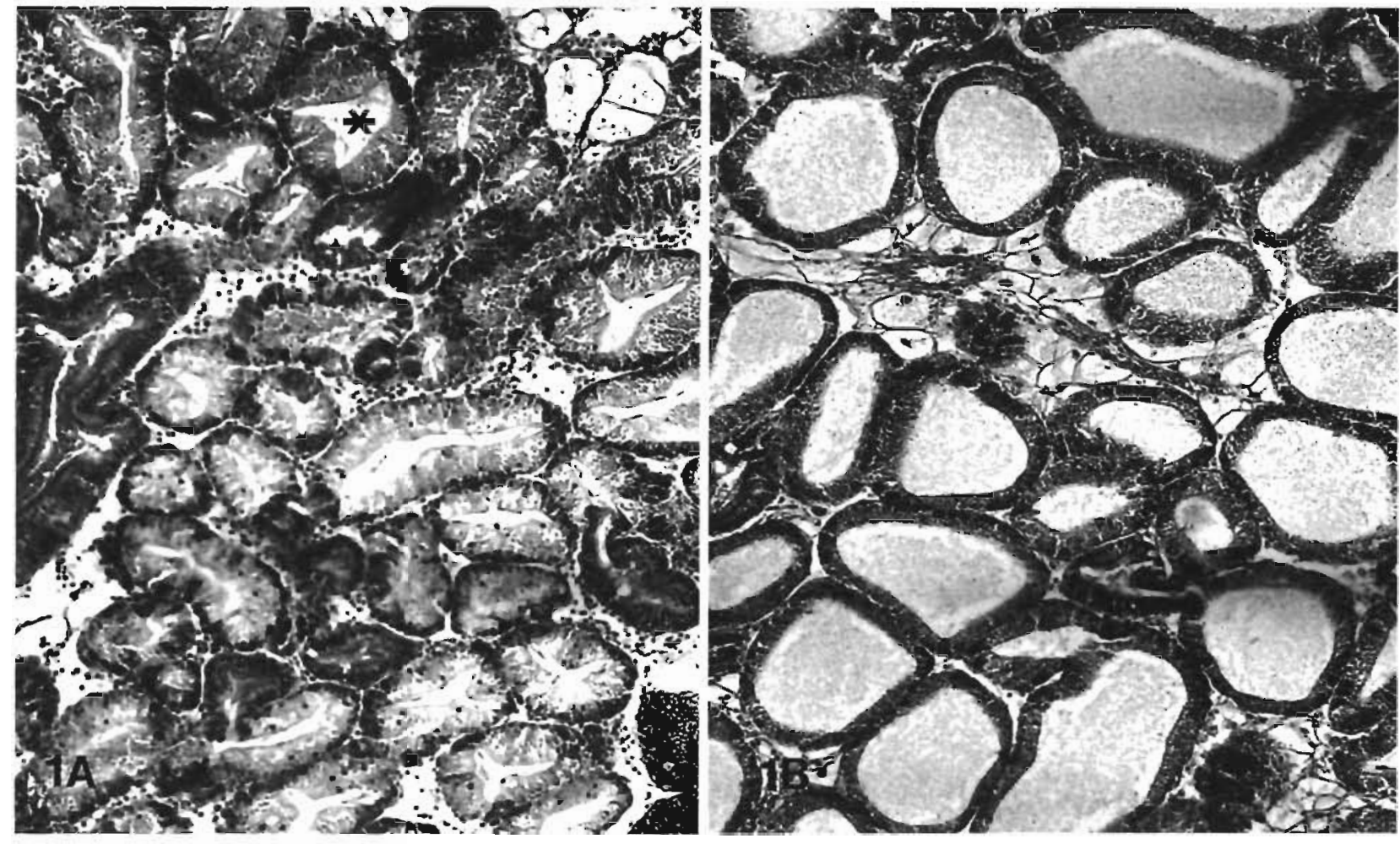

Fig. 1. Crassostrea virginica. Histological preparations of cross-sections through oyster soft tissues, demonstrating healthy and metaplastic digestive gland diverticula $(\mathrm{H} \& \mathrm{E}, \times 160)$. (A) shows predominantly normal (type $\mathrm{A})$ diverticula, except for one type $B$ (*). (B) shows severe metaplastic change, type $C$, with dilation of lumina and loss of cell height; type D (not shown) would also have necrotic cells sloughed into the lumina. Typing of metaplasia is done after Couch (1985)

Some of the canal oysters were greenish in color in both January and May collections, but in January this coloration was subtle. Copper was concentrated much more than $\mathrm{Cr}$ or As. Copper concentrations in canal oysters were greater in May than in January (Fig. 2). The small $(<1$ yr old) oysters growing on the new piling in the canal had the highest concentrations of all the oysters sampled (Fig. 2). A slight negative correlation was found in the winter collection between oyster soft tissue weight and $\mathrm{Cu}$ concentration (slope = $-11.12, y$-intercept $=183, r=0.644$ for the canal collection; and slope $=-1.349, \mathrm{y}$-intercept $=15.14, \mathrm{r}=0.506$ for the reference collection). The regression lines are illustrated in Fig. 3A, B. Tissue contents of As did not correlate with oyster size.

The transplanted oysters rapidly accumulated elevated $\mathrm{Cu}$ levels (Fig. 4). They also exhibited a slight negative correlation of weight with $\mathrm{Cu}$, but not $\mathrm{As}$, concentration. After $1 \mathrm{mo}$, slope $=-6.09, \mathrm{y}$-intercept $=$ $67.0, r=0.551$; after 2 mo, slope $=-7.608, y$-intercept $=$ 112, $r=0.616$ (see Fig. 3C, D).

The granular hemocytes on the mantle surface of canal and transplanted oysters were only of the acidophilic type. The basophilic hemocytes, which com- posed about one-fourth of the total hemocytes in the reference oysters, were rare or non-existent.

\section{DISCUSSION}

Digestive diverticulum atrophy, or metaplasia, in oysters has been described by Couch $(1984,1985)$ as a non-specific response to stressful environmental conditions, such as certain toxic chemicals and physiological stresses caused by freshets, starvation, and possibly even spawning (Couch unpubl. obs). Our data indicate that conditions inside the canal cause an increase in the prevalence and severity of this tissue response, although reference oysters transplanted to the canal for 3 mo did not exhibit the response despite elevated body burdens of copper. This may indicate that a longer time of exposure may be necessary for metaplasia to manifest itself under the environmental conditions within this canal, or that transient adaptation of diverticula cells to minimal stress had occurred.

The same pathological condition has previously been reported in oysters exposed to copper $(0.1$ to $0.5 \mathrm{ppm}$ ) for $2 \mathrm{wk}$ in the laboratory (Fujiya 1960). Prev- 


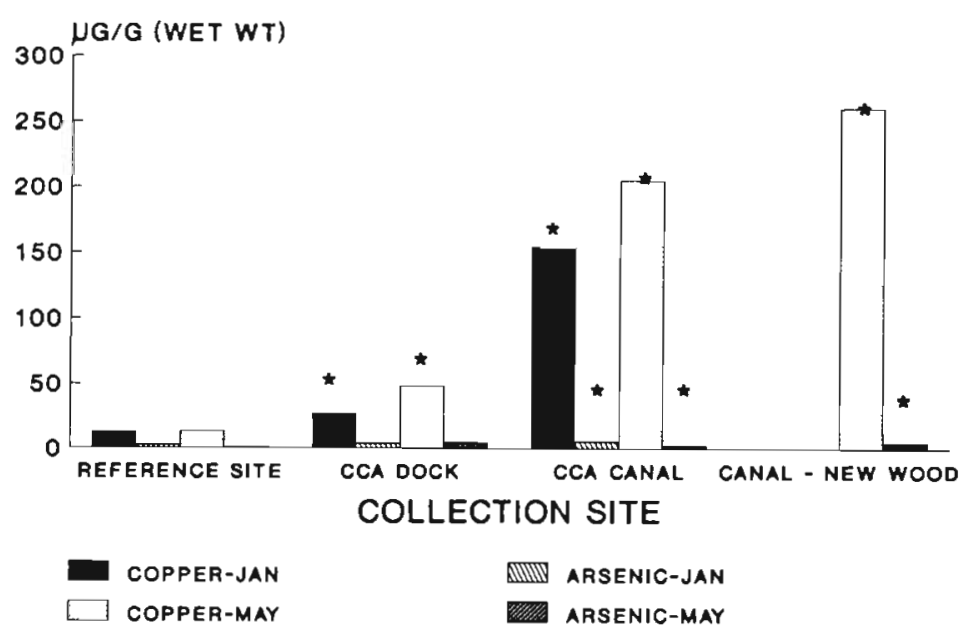

Fig. 2. Crassostrea virginica. Metal concentrations in oysters from 3 sites. The newly placed CCA-treated wood was sampled only in May. Significant (indicated by $\star$ by Bonferroni) t-values for January: ref. vs canal Cu: $t=29.5$; ref. vs dock Cu: $t=4.925$ (Bonferroni); ref. vs canal As: $t=3.42$. For May: ref. vs canal Cu: $t=9.58$; ref. vs dock Cu: $t=4.46$; ref. vs canal As: $t=3.59$; ref. vs dock As: $t=2.75$ ious investigations have also noted these lesions in oysters injected with turpentine (Pauley \& Sparks 1965) or exposed to environmental levels of PCBs (Aroclor 1254) in flowing seawater (Lowe et al. 1972).

Other investigators have found these lesions in mussels exposed to, among other chemicals, copper. Auffret (1988) described the condition in mussels from contaminated field sites as well as in mussels experimentally exposed to $20 \mathrm{\mu g} \mathrm{l}^{-1}$ of copper in the laboratory. Mussels exposed to dimethylnitrosamine also developed metaplasia of the digestive diverticulae (Rasmussen 1982). The condition was observed in both field- and lab-exposed Mytilus edulis by Lowe (1988) who correlated lesions (tubule dilation, cell shrinkage and erosion) with disturbance in lipid metabolism, reflected in accumulation of neutral lipids, which was related to metal and organic chemical contamination. Moore (1988) believed

\section{A CU VS WEIGHT IN OYSTERS REFERENCE SITE}

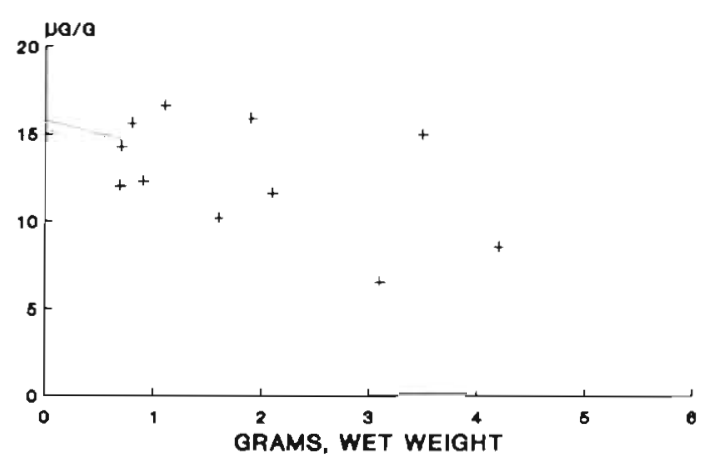

C CU VS WEIGHT IN OYSTERS TRANSPLANTS, ONE MONTH

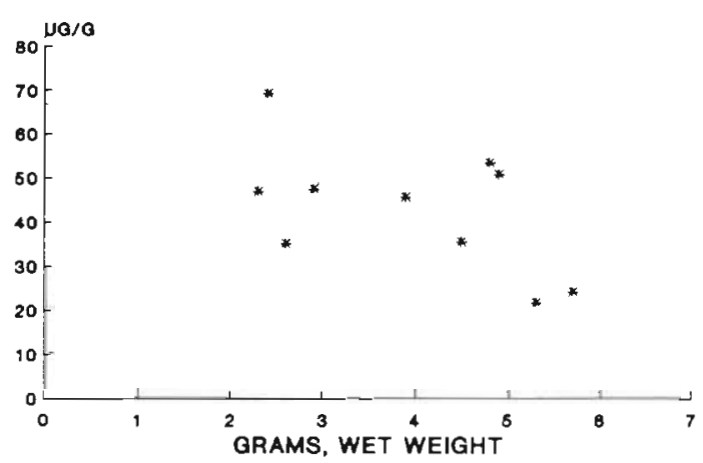

B CU VS WEIGHT IN OYSTERS CANAL SITE

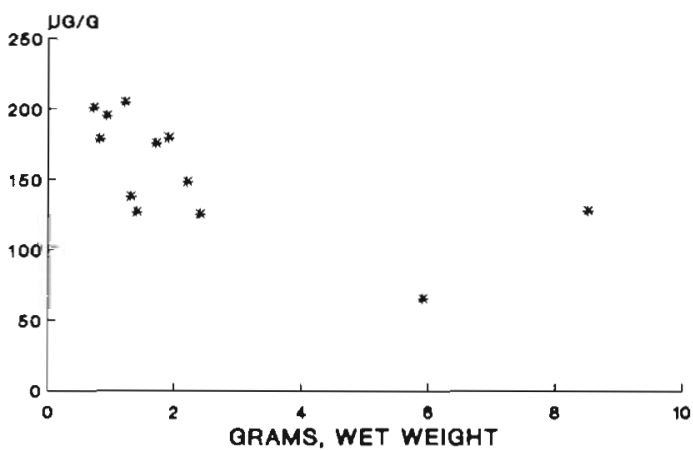

D CU VS WEIGHT IN OYSTERS TRANSPLANTS, TWO MONTHS

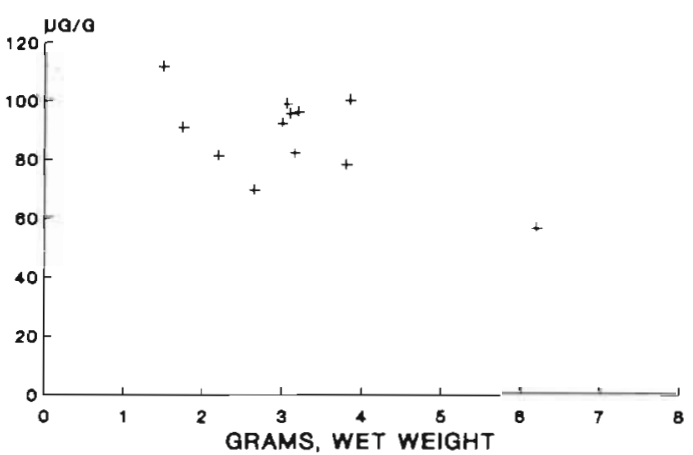

Fig. 3. Crassostrea virginica. Linear regression analyses of relationship between oyster size (soft tissue wet weight) and copper concentrations. (A) and (B) show reference and canal populations. (C) and (D) show reference oysters transplanted to the canal for 1 and 2 mo, respectively. Note the different $y$-axis scales; see text for slopes, intercepts, and correlation coefficients 


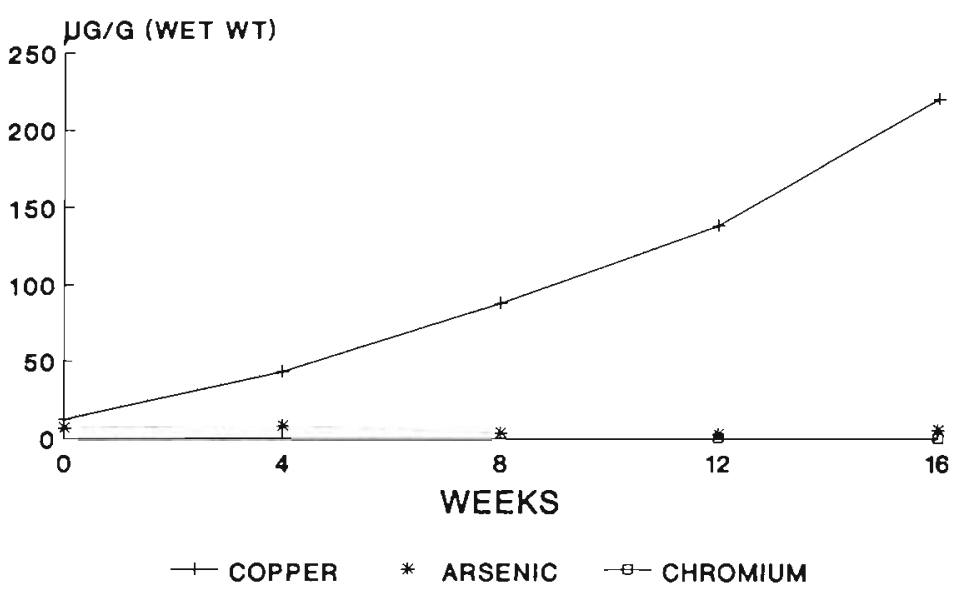

Fig. 4. Crassostrea virginica. Metal concentrations in transplanted reference oysters over the 4 mo sampling period

that an increase in neutral lipids caused lysosomal accumulation of lipids, resulting in reduced membrane stability and increased lysosomal fragility, which then caused increased autophagy of lipids in the digestive cells.

The transplanted oysters acquired significantly elevated levels of $\mathrm{Cu}$, although at the time of histological examination, they had only about two-thirds of the canal oysters' copper; at this time, there were no differences in the extent of digestive gland lesions when compared with the reference oysters. The overall condition of both reference and canal specimens in May was poorer than in January, indicating that the onset of reproductive activity (histological examination showed them all to be ripe), warmer temperature, etc., may have caused additional stress. There was no significant difference between the sexes in either population.

Our finding of highly elevated $\mathrm{Cu}$ concentrations but only modest elevations of As (and neglible accumulation of $\mathrm{Cr}$ ) is consistent with the literature. Schuster \& Pringle (1969) found that accumulation of $\mathrm{Cr}$ in exposed oysters was an order of magnitude below that of $\mathrm{Cd}$ and 2 orders of magnitude below that of $\mathrm{Cu}$.

The finding of a slight negative correlation of oyster weight with copper concentration was in agreement with a number of other reports indicating an inverse relation of some metals with size in bivalves. Zaroogian (1980) found an inverse correlation of $\mathrm{Cd}$ concentration with oyster Crassostrea virginica size. Boyden (1977) found Cu concentration was inversely related to size in $C$. gigas. Metal concentrations decreasing with body size was believed to indicate that a significant proportion of the metal content is surface absorbed, since smaller organisms have a larger surface-to-volume ratio (White \& Rainbow 1987). Mackay et al. (1975) proposed that the growth rate is greater than the metal accumulation rate, thus causing de- creased concentrations in the larger oysters. This size/copper relationship has negative implications for oyster predators, such as the Florida rock snail Thais hemastoma floridae which preferentially eats the smaller, more vulnerable oysters and thereby acquires greater Cu burdens (Weis \& Weis 1993).

Granular hemocytes were described by Ruddell (1971) as being of 2 types, acidophilic and basophilic. The acidophils were associated with $\mathrm{Cu}$ and the basophils with $\mathrm{Zn}$. His histochemical demonstration was corroborated by electron microprobe analysis (George et al. 1978, Thompson et al. 1985). The basophilic hemocyte population was absent in our canal and transplant oysters. It is not known whether this represents a shift in hemocyte differentiation in response to environmental $\mathrm{Cu}$ or to a physiological change brought about in differentiated cells by the Cu stress.

In view of the high copper concentration in the canal oysters and of the previous studies linking the metaplasia to copper, it is likely that the copper from the wood was primarily responsible for the lesions. However, there are other sources of stress in the canal environment which could also contribute to the state of the oysters. In addition to the metals from the treated wood, the canal has boating activity which could add hydrocarbons and additional $\mathrm{Cu}$ from antifouling paint. There is also a possibility that runoff of lawn chemicals from land adjacent to the canal could contribute to the poor health of the oysters. It is clear that such residential CCA wood-lined canals are not healthy environments for oysters.

Acknowledgements. This work was performed while P.W. and J.S.W. were visiting scientists at the EPA Gulf Breeze Laboratory and P.W was partially supported by a National Research Council - U.S. EPA Senior Research Associateship. We thank many members of the staff for their hospitality and generosity, and we especially thank Jeanne Micari for technical assistance.

\section{LITERATURE CITED}

Auffret, M. (1988). Histopathological changes related to chemical contamination in Mytilus edulis from field and experimental conditions. Mar. Ecol. Prog. Ser. 46: 101-107

Boyden, C. R. (1977). Effect of size upon metal content of shellfish. J. mar. biol. Ass. U.K. 57: 675-714

Couch, J. (1984). Atrophy of diverticular epithelium as an indicator of environmental irritants in the oyster, Crassostrea virginica. Mar. environ. Res. 14: 525-526

Couch, J. (1985). Prospective study of infectious and noninfectious diseases in oysters and fishes in three Gulf of Mexico estuaries. Dis. aquat. Org. 1: 59-82

Fujiya, M. (1960). Studies on effects of copper dissolved in sea water on oysters. Bull. Jap. Soc. scient. Fish. 26: 462-468 
George, S. G., Pirie, B. J., Cheyne, A. R., Coombs, T. L., Grant. P. T (1978). Detoxication of metals by marine bivalves: an ultrastructural study of the compartmentation of copper and zinc in the oyster, Ostrea edulis. Mar. Biol. 45: $147-156$

Lankester, E. R. (1986). On green oysters. Q. J. microsc Sci. 26: $71-94$

Lowe, D. M. (1988). Alteration in cellular structure of Mytilus edulis resulting from exposure to environmental contaminants under field and experimental conditions. Mar. Ecol. Prog. Ser. 46: 91-100

Lowe, J. I, Parrish, P. R., Patrick, J. M. Jr, Forester, J. (1972). Effects of the polychlorinated biphenyl Aroclor 1254 on the American oyster, Crassostrea virginica. Mar. Biol. 17: $209-214$

Mackay, N. J., Williams, R. J., Kacprzac, J. L., Kazacos, M. N., Collins, A. J., Auty, E. N. (1975). Heavy metals in cultivated oysters (Crassostrea virginica = Saccostrea cucul lata) from the estuaries of New South Wales. Aust. J. mar. Freshwat. Res. 26: 31-46

Mehta, C., Patel, N. (1991). StatXact: statistical software for exact nonparametric inference, version 2 edn. Cytel Corp., Cambridge, MA

Moore, M. N. (1988). Cytochemical responses of the lysosomal system and NADPH-ferrihemoprotein reductase in molluscan digestive cells to environmental and experimental exposure to xenobiotics. Mar. Ecol. Prog. Ser. 46: $81-89$

Pauley, G. B., Sparks, A. K. (1965). Preliminary observations on the acute inflammatory reaction in the Pacific oyster, Crassostrea gigas (Thunberg). J. Invertebr Pathol. 7 : $248-256$

Rasmussen, L. (1982). Light microscopical studies of the acute toxic effects of $\mathrm{N}$-nitrosodimethylamine on the marine mussel, Mytilus edulis. J. Invertebr. Pathol. 14: $266-267$

Responsible Subject Editor: A. K. Sparks, Seattle, Washington, USA
Ruddell, C. L. (1971). Elucidation of the nature and function of the granular oyster amebocytes through histochemical studies of normal and traumatized oyster tissues. Histochemie 26: 95-112

Schuster, C. N., Pringle, B. H. (1969). Trace metal accumulation by the American oyster, Crassostrea virginica. Proc. natl Shellfish. Ass. 59: 91-103

Thompson, J. D., Pirie, B. J., George, S. G. (1985). Cellular metal distribution in the Pacific oyster, Crassostrea gigas (Thun.) determined by quantitative $x$-ray microprobe analysis. J. exp. mar. Biol. Ecol. 85: 37-45

Warner, J. E., Solomon, K. R. (1990). Acidity as a factor in leaching of copper, chromium, and arsenic from CCAtreated dimension lumber. Environ. Toxicol. Chem. 9: $1331-1337$

Weis, J. S., Weis, P. (1992). Transfer of contaminants from CCA-treated wood to estuarine biota. J. exp. mar. Biol. Ecol. 161: 189-199.

Weis, J. S., Weis, P. (1993). Trophic transfer of contamınants from organisms living by chromated-copper-arsenate (CCA)-treated wood to their predators. J. exp. mar. Biol. Ecol. 168: 25-34

Weis, P., Weis, J. S., Coohill, L. (1991). Toxicity to estuarine organisms of leachates from chromated copper arsenate treated wood. Archs environ. Contam. Toxicol. 20: $188-194$

Weis, P., Weis, J. S., Greenberg, A., Nosker, T. J. (1992). Toxicity of construction materials in the marine environment: a comparison of chromated-copper-arsenatetreated wood and recycled plastic. Archs environ. Contam. Toxicol. 22: 99-106

White, S. L., Rainbow, P. S. (1987). Heavy metal concentration and size effects in the mesopelagic decapod crustacean Systellapis debilis. Mar. Ecol. Prog. Ser. 37: 147-151

Zaroogian, G. E. (1980). Crassostrea virginica as an indicator of cadmium pollution. Mar. Biol. 58: 275-284

Manuscript first received: December 9, 1992

Revised version accepted: May 12, 1993 